\title{
APRESENTAÇÃo - Ecos Do11/09. O DIA EM QUE TUDO MUDOU?
}

\author{
Ariana Bazzano $^{1}$ e Silvana Mariano ${ }^{2}$
}

\begin{abstract}
$\Omega^{e}$ omo cientistas sociais, conhecemos o risco de se pensar uma mudança estrutural a partir de uma única data. Contudo, existem razões para crer que os atentados de 11 de setembro de 2001 podem ser considerados um marco político do início do século XXI. Além das consequências imediatas dos ataques, como a morte das vítimas e o choque que abalou as grandes potências globais ao longo da última década, o mundo testemunhou desdobramentos até então impensáveis, após o fim da Guerra Fria: as guerras preventivas, a suspensão dos direitos civis em nome da segurança nacional em parte das democracias ocidentais, as violações dos direitos humanos, as detenções arbitrárias em nome do combate ao terrorismo e o visível acirramento das questões relativas à imigração e à diversidade cultural, especialmente no que respeita às comunidades islâmicas, em várias regiões do planeta.
\end{abstract}

Sabemos que o 11 de setembro de 2001 não é o responsável exclusivo por todos esses fatos, mas certamente, os atentados foram a "desculpa" perfeita e/ou o catalisador de vários desses processos. Diante deste (ideo)panorama, o dossiê pretendeu abrigar análises de diversos campos, como o da Sociologia, da Antropologia, da Ciência Política e das Relações Internacionais, que se proponham a discutir as implicações políticas, econômicas, sociais e culturais dos atentados, e a resposta dos mais diversos atores nestes últimos 10 anos. 0 nome deste dossiê, "Ecos do 11/09 - Dez anos depois", expressa bem a intenção dos autores dos

\footnotetext{
${ }^{1}$ Doutoranda em Relações Internacionais pelo PPGRI San Tiago Dantas, Brasil. arianabazzano@ gmail.com

${ }^{2}$ Professora do Departamento de Ciências Sociais e Programa de Pós Graduação em Ciências Sociais - Universidade Estadual de Londrina, Brasil. silvanamariano@yahoo.com.br
} 
artigos: evidenciar o ressoar, os efeitos, enfim, as consequências sócio-políticas dos atentados, ao longo de uma década.

Gayatri Spivak afirma que escreve o seu texto em resposta à guerra dos Estados Unidos contra o terrorismo. Ela diz que parte da convicção de que não existe uma resposta possível à guerra, porém, dentro do contexto da "guerra ao terror", não se pode calar. Assim, ela constrói o seu texto a partir de duas questões bem pertinentes e atuais: "Quais são algumas das respostas já existentes? E: como responder diante da impossibilidade de oferecer uma resposta?". Spivak busca uma resposta orientada pelo entendimento de que "a cultura é sua própria explicação" e exercita a partir daí um olhar de aproximação com o "outro", para compreender tanto os "atentados suicidas" quanto a guerra estadunidense contra o terrorismo. Ao construir sua resposta, Spivak critica as explicações estereotipadas formuladas pela direita e pela esquerda nos EUA. Seu texto contribui para problematizar criticamente a própria ideia de "terror" e "terrorismo", bem como interpela 0 sentido de "forças de manutenção de paz" ao invocar as denúncias de práticas recorrentes de estupros de mulheres e tráfico de mulheres e de crianças.

Andrei Koerner e Marcelo Campos apontam como a literatura anglo-saxã sobre segurança pública pensa o papel dos Estados Unidos na América Latina, no cenário pós- 11/09. Os autores destacam que a "guerra ao terror" se tornou o eixo das relações bilaterais estabelecidas pelos Estados Unidos com os outros países, o que trouxe modificações no plano da formulação e implementação das políticas de segurança em diversos países do globo.

Cristina Pacheco tem como foco as instituições domésticas norteamericanas. Por meio da análise das decisões da Suprema Corte dos Estados Unidos, a autora ressalta que os atentados de 11/09 não apenas se constituíram em um elemento de ruptura da ordem estabelecida no plano doméstico ao longo da história do país, como também permitiu, ainda que por um breve período, a instauração de um desequilíbrio entre as instituições americanas, no qual o Executivo ocupou um espaço significativo em relação aos outros poderes.

Inserido nas recentes reflexões sociológicas de Chomsky, Wacquant, Garland e Bauman, o texto de Débora Pastana retrata que o atual combate ao terror contribui para consolidar, ao menos no Ocidente, a figura do "Estado punitivo". A autora destaca que, paradoxalmente, a defesa dos ideais democráticos e a necessidade de políticas autoritárias de controle social se propagaram por 
quase todos os países, sendo a política de "guerra ao terror", o elo entre esses dois discursos.

Com um olhar sobre o Brasil, Roberto Menezes, examina em que medida os eventos de 11 de setembro de 2001 contribuíram para a revisão da inserção internacional do Brasil e de como eles influíram na elaboração de uma nova estratégia no governo Lula da Silva (2003-2010). As principais mudanças na agenda externa brasileira, citadas pelo autor são: a derrocada das negociações da ALCA, a busca de uma inserção soberana e o fortalecimento de uma ordem multipolar.

Ana Tostes observa como os atentados do 11/09 reverberaram na sociedade civil, especialmente nos chamados "grupos de ódio". A autora procura contribuir para o entendimento, tanto da mudança de concepção de "terrorismo", quanto da identificação de efeitos desta mudança refletidos em novos enquadramentos de crimes de ódio, na classificação e mapeamento das ações de grupos extremistas norte-americanos de direita.

A partir da expressão "polícia do mundo", Geraldo Teixeira aponta como a prática de policiamento internacional ganhou contornos mais frequentes e agressivos pós-11 de setembro de 2001. Sendo as "extraordinary renditions" e as práticas a ela associadas, como a tortura e as prisões secretas dos Estados Unidos no exterior, o símbolo desse novo policiamento internacional. Para o autor, é preocupante notar que essas práticas adquirem legitimidade quando associadas ao discurso de combate do terrorismo internacional.

As análises sobre o terrorismo normalmente estão associadas aos estudos de segurança internacional. Neste dossiê, estes estudos estão contemplados pelo artigo de Cléber Lopes. A "guerra ao terror" proporcionou um grande aumento do uso de empresas privadas de segurança em zonas de conflito e no âmbito doméstico norte-americano. Com o foco para a segurança interna dos Estados Unidos, o autor discute os desafios e implicações que a segurança privada coloca para a governança da segurança nacional dos Estados Unidos no período pós-11/09.

Por meio da sociologia do cinema, Héder Santos e Luana Chaves trabalham em seu artigo, através do filme Yasmin, as delicadas relações de identidade cultural e a construção do discurso do "inimigo", neste caso o islâmico, no contexto pós11/09. 0 filme Yasmin (Inglaterra/ Alemanha, 2004), do diretor escocês Kenneth Glenaan, mostra a vida de imigrantes paquistaneses, moradores de um subúrbio 
na Inglaterra que veem as suas vidas fortemente afetadas pela repercussão destes atentados.

Explorando a definição de "áreas não-governadas", o artigo de Aline Pavan e Luiza Mateo analisa como por meio desse controverso conceito, os Estados Unidos lidam em sua política externa para a América do Sul com os problemas de segurança internacional, especialmente, o terrorismo. Através da visão do Departamento do Estado dos Estados Unidos e da Agência dos Estados Unidos para o Desenvolvimento Internacional, as autoras procuram identificar, especialmente, no Governo Obama, como essas agências percebem e auxiliam as regiões que eles identificam como "áreas não-governadas" na América do Sul.

Os artigos apresentados acima, apesar de explorarem diversos aspectos da vida social, compartilham um certo "tom pessimista" em suas análises, especialmente no que se refere ao papel exercido pelos Estados Unidos na condução da "guerra ao terror" e à situação contemporânea dos direitos humanos. 0 clima de otimismo da década de 1990, derivado do fim da Guerra Fria, da globalização e da expansão dos direitos humanos, foi substituído na primeira década dos anos 2000 por um clima de medo, busca por segurança militar e recrudescimento dos nacionalismos.

Dessa forma, a seleção de artigos que compõem este dossiê apresenta, com a diversidade de perspectivas e de metodologias, as diferentes formas exploradas pelas ciências sociais e humanas para a produção de pesquisas sociais em torno de fenômenos contemporâneos. Nas diferentes dimensões da realidade social, novos fenômenos e eventos desafiam o emprego de conceitos e categorias de análise já consolidados, bem como estimulam, em certas circunstâncias, novas produções teóricas. As reflexões aqui apresentadas pretendem contribuir para esse processo de produção do conhecimento e para lançar luz sobre nossa realidade atual. 